\title{
Senior Homeless Population was Covid-19 Free in 3 shelter communities after adapting the Life Island model (Note)
}

\author{
P. Gombita (Peter Gombita)', M. Olah (Michal Olah)², R. Kovac (Robert Kovac)², \\ M. Jurasek (Martin Jurasek)4', M. Kosticova (Michaela Kosticova)', M. Taziarova \\ (Marta Taziarova) $^{6}$, S. Zabavova (Silvia Zabavova)4 , E. Haluskova \\ (Eva Haluskova) ${ }^{4}$, M. Jackulikova (Maria Jackulikova) ${ }^{3}$, P. Zemko (Pavol Zemko)3, \\ M. Katunska (Monika Katunska)2, J. Adamcova (Jana Adamcova)4), J. Bozik \\ (Jozef Bozik) ${ }^{4}$, I. Rac (Ivan Rac) ${ }^{7}$, K. Bundzelova (Katarina Bundzelova) \\ A. Pavlovicova (Anna Pavlovicova)5), W. Maszlak (Wladimierz Maszlak)5, D. Tonzar \\ (David Tonzar) $^{5}$
}

${ }^{1}$ Oasis of Freedom Homeless Program Bernatfalva and Hidasnemethy, Hungary

Original Article

${ }^{2}$ Mea Culpa Shelter SEUC Homeless Program Bratislava, Slovakia.

${ }^{3}$ UNHCR and St. Elizabeth University Refugee Program, Lesbos, Greece.

${ }^{4}$ St. John Paul Institute of Missiology Polianky and Jan Hus Institute of Missiology, Slovakia.

${ }^{5}$ Prague, Czech Republic, AKH University General Hospital Vienna, Austri.

${ }^{6}$ Equita, c. a., Bratislava, Slovakia.

${ }^{7}$ Institute of Romological Studies, Faculty of Social Sciences and Health Care, Constantine the Philosopher University, Ruzomberok, Slovakia

\section{E-mail address:}

gombitap@gmail.com

\section{Reprint address:}

Peter Gombita

Oasis of Freedom Homeless Program Bernatfalva and Hidasnemethy

Hidasnemethy

Hungary

Source: Clinical Social Work and Health Intervention

Volume: 11

Issue: 3

Pages: $78-79$

Cited references: 1

\section{Reviewers:}

Selvaraj Subramanian

SAARM Kuala Lumpur, Malaysia

Catherine Mulama

Naivasha, Kenya

\section{Keywords:}

Covid-19. Seniors/Elderly. Social Work. Clients.

\section{Publisher:}

International Society of Applied Preventive Medicine i-gap

CSWHI 2020; 11(3): 78 - 79; DOI: 10.22359/cswhi_11_3_12 (C) Clinical Social Work and Health Intervention 


\section{Abstract:}

\section{Introduction}

The Covid-19 pandemic is related with higher mortality especially among senior/elderly homogenous groups such as elderly nursing homes, mental facilities and homeless shelters(l).

The aim of this research note is to show three examples in different senior/elderly shelters for homeless which remained completely disease free during the March to June periods of first and second waves of the Covid-19 pandemics, and describe modus vivendi (way of life) and modus operandi (way of working) in those facilities.

\section{Methods, study population}

Three independent shelters $1^{\text {st }}$ on the SK/HU border with 145 clients serving for two large cities; $2^{\text {nd }}$ on SK/AT border with 31 clients; $3^{\text {rd }}$ near SK/PL boundary with 155 clients were studied; all more than 60 years of age. Partial quarantine was measured with the frequency of in and out visits, and, Covid-19 Ab tests were performed either for presence of antibodies (historic infection) and in symptomatic with PCRCovid-19 tests, between March 30 and June 30, 2020.

\section{Results and discussion}

All three shelters did not report any single positive case of Covid-19 and there was just 1 case of historic infection (ab test positive but PCR negative) in all 331 homeless senior clients.

Several reasons were probably responsible for this unexpected result:

1. Semi-Quarantine characterized our visits with staying in during the first month and very limited out during second and third months and avoiding outside visits for shopping, sports, cultural or leisure events

2. Incentives such as free cigarettes, free food $3 x$ or $2 \mathrm{x}$ daily

3. Medical care by GP visits daily Inhouse avoiding visits to hospitals or doctor's offices

4. Free medicine supplies for unconnected diseases
5. Religious and cultural events inhouse

6. TV, computer and other free media services inhouse

\section{Conclusions}

With joint health, social care and incentives, the model of life island in all three facilities despite peak epidemic events resulted in Covid-19 free environments and prevented spread of the disease in high risk communities such as sheltered elderly homeless populations. In contrast to several EU countries, overall mortality among seniors in Slovakia such as in Austria and Hungary was lower than in most western EU countries e.g. France, UK, Belgium, Italy and Spain, probably due to very early intervention, including semi-quarantine and free social and health services incentive systems.

\section{References:}

1. WHO QUARTERLY REPORT (2020) Geneva World Health Organisation, www. https.Who. $\operatorname{org} .2020$. 